\title{
Factors affecting career choice of students in a medical faculty
}

\author{
Bir tıp fakültesi öğrencilerinin meslek seçimini etkileyen faktörler
}

\author{
Sibel Öner Yalçın, Nevzat Atalay Çelikyürek, Hande Şenol, Kamil Fatih Türker, Okan Yavuz, Mert \\ Can Kaya, Mert Bozdağ
}

Gönderilme tarihi:03.06.2021

Kabul tarihi:02.07.2021

\begin{abstract}
Purpose: Career choice is a complex process where individual and environmental factors are effective. Medicine is one of occupational disciplines which is preferred most by young people who are successfull in the numerical subjects in Turkey. This study was carried out to determine the factors that affect the career choices of first-year students in the faculty of medicine at a state university.

Materials and methods: The study was a descriptive cross-sectional which was performed with the participation of first-year students $(n=167)$ between March 1, 2020 and March 30, 2020 after the ethics committee approval was obtained. Data were collected by online survey method and analyzed with SPSS 25.0 package program. We evaluated 11 factors, which we thought to be effective in the choice of medical faculty, with a 5-point Likert type scale. Descriptive statistics were expressed in numbers and percentage and numerical data were expressed in mean and standard deviation. The Mann-Whitney $U$ test was used for comparisons. Statistical significance level was accepted as $p<0.05$.

Results: A total of $58.1 \%$ of the students participating in the study were female and $41.9 \%$ were male. The factor that was considered most important by the students in their choice of profession with a rate of $36.5 \%$ was the certainty of employment of physicians. It was followed by helping people with a rate of $53.9 \%$ and being a respected profession in the society with a rate of $53.3 \%$. More male students than female students stated that they chose medicine because they wanted to earn more money $(p<0.05)$.

Conclusion: The results of the study showed that the most important factor in choosing medical career of first-year students in medical faculty was the certainty of employment. It was followed by helping people and medicine as a respected profession.
\end{abstract}

Key words: Medical school, medical students, career choice.

Oner Yalcin S, Celikyurek NA, Senol H, Turker KF, Yavuz O, Kaya MC, Bozdag M. Factors affecting career choice of students in a medical faculty. Pam Med J 2022;15:37-44.

Öz

Amaç: Meslek seçimi, bireysel ve çevresel faktörlerin etkili olduğu karmaşık bir süreçtir. Hekimlik Türkiye'de sayısal alanda başarılı olan gençlerin en çok tercih ettiği mesleklerden biridir. Bu araştırma bir devlet üniversitesinde öğrenim gören tıp fakültesi birinci sınıf öğrencilerinin meslek tercihlerinde etkili olan faktörleri belirlemek amacıyla yapılmıştır.

Gereç ve yöntem: Bu araştırma etik kurul onayı alındıktan sonra (2020/07), 1 Mart 2020-30 Mart 2020 tarihleri arasında birinci sınıf öğrencilerinin $(n=167)$ katılımıyla tanımlayıcı kesitsel olarak yapılmıştır. Veriler online anket yöntemiyle toplanmış ve SPSS 25.0 paket programı ile analiz edilmiştir. Tıp fakültesi seçiminde etkili olduğunu düşündüğümüz 11 faktör 5'li Likert tipi ölçekle değerlendirilmiştir. Tanımlayıcı istatistiklerde sayı ve yüzde, sayısal veriler için ortalama ve standart sapma, karşılaştırmalarda Mann Whitney U testi kullanılmıştır. İstatistiksel anlamlılık düzeyi $p<0,05$ kabul edilmiştir.

Bulgular: Araştırmaya katılan öğrencilerin \%58,1'i kız, \%41,9'u erkektir. Öğrencilerin meslek seçiminde en önemli buldukları faktör \%36,5 oranında hekimlerin meslek sahibi olma garantisidir. Bunun yanında $\% 53,9$ oranında insanlara yardım etmek isteği, \%53,3oranında hekimliğin toplumda saygı duyulan bir meslek olması önemli olmuştur. Erkek öğrenciler kız öğrencilere göre daha çok para kazanmak istedikleri için hekimliği seçtiklerini belirtmiştir $(p<0,05)$.

Sibel Oner Yalcin, PhD, MSc, Asist. Prof. Pamukkale University, Faculty of Medicine, Department of Medical Ethics and History. Denizli, Turkey, e-mail: sibelemreduygu@gmail.com (https://orcid.org/0000-0002-6122-7087) (Corresponding Author)

Nevzat Atalay Çelikyürek, MD, Research Assistant, Pamukkale University Faculty of Medicine, Department of Public Health, Denizli, Turkey, e-mail: atalaycelikyurek@gmail.com (https://orcid.org/0000-0001-9731-8880)

Hande Şenol, PhD. MSc, Asist. Prof. Pamukkale University Faculty of Medicine, Department of Biostatistics, Faculty Member, Denizli, Turkey, e-mail: handesenol@gmail.com (https://orcid.org/0000-0001-6395-7924)

Kamil Fatih Türker, Pamukkale University Faculty of Medicine Second Class Student, Denizli, Turkey, e-mail: fatihturker@outlook.com (https:// orcid.org/0000-0003-3884-9475)

Okan Yavuz, Pamukkale University Faculty of Medicine Second Class Student, Denizli, Turkey, e-mail: yavuzokan020@gmail.com (https:// orcid.org/0000-0002-1403-9307)

Mert Can Kaya, Pamukkale University Faculty of Medicine Second Class Student, Denizli, Turkey, e-mail: remixbyd55_1907_@hotmail.com (https://orcid.org/ 0000-0002-5838-3011)

Mert Bozdağ, Pamukkale University Faculty of Medicine Second Class Student, Denizli, Turkey, e-mail: bozdag.mert@hotmail.com (https:// orcid.org/0000-0003-2161-4856) 
Sonuç: Bu araştırmanın sonuçlarına göre tıp fakültesi birinci sınıf öğrencilerinin hekimlik mesleğini seçmelerinde en önemli faktör meslek sahibi olma garantisidir. Bunu insanları sevmek ve hekimliğin saygın bir meslek olması takip etmektedir. Bulgularımızın hekim olmak isteyen öğrenciler, eğitimciler, politika planlayıcılar için yararlı olmasını umut ediyoruz.

Anahtar kelimeler: Tıp fakültesi, tıp öğrencileri, meslek seçimi.

Öner Yalçın S, Çelikyürek NA, Şenol H, Türker KF, Yavuz O, Kaya MC, Bozdağ M. Bir tıp fakültesi öğrencilerinin meslek seçimini etkileyen faktörler. Pam Tıp Derg 2022;15:37-44.

\section{Introduction}

Career choice is a complex process affected by many factors. Environmental factors such as coincidences, family, life conditions, cultural and socio-economic conditions of countries are usually effective in career choice, as well as individual factors such as personal areas of interest, abilities, personality traits, and value judgements [1-3]. It makes the career choice process even more difficult while taking exams like being in a race. Many young people do not have the opportunity to choose a profession based on their skills and areas of interest as it is a known fact that environmental conditions and economic difficulties significantly affect their choice of profession.

There have been many changes in the understanding and practice of medicine over time. However, medicine has always been one of the professions in which young people take an interest. Physicians are the main actors who serve to the notion of "being healthy" which is the most important value for people. In the literature, it is seen that the students who chose the profession of medicine were affected by the factors of "the desire to help people" [4-7], "the respectability of medicine" $[8,9]$ and "economic conditions provided by the profession" [10-13].

In Turkey, about 2 million people take matriculation exam conducted by Student Selection and Placement Centre (ÖSYM) every year [14]. In order to enroll in medical faculty of one of state universities, it is necessary to rank in the first nineteen thousand in maths as of 2019-2020 [15]. This study was performed to compare the factors of first-year students in the Faculty of Medicine, Pamukkale University, which are stated below;

a) Those influencing their choice of medical profession,

b) Those affecting the choice of medical profession together with some demographic data.

\section{Materials and methods}

The study was a descriptive cross-sectional study. For the power analysis using $\mathrm{G}^{*}$ Power 3.1 and medium effect size was considered and power was considered $85 \%$. Thus, 146 individuals for minimum sample size were found. The study population consisted of 167 students who were in the first year in Faculty of Medicine, Pamukkale University during 20192020 academic year.

The study approval was obtained from the Non-Interventional Ethics Committee of the Faculty of Medicine, Pamukkale University and the Dean's Office of the Faculty of Medicine.

The study data were collected via an online questionnaire provided to the students who were at home due to Covid-19 pandemic between March 15, 2020 and March 30, 2020.

\section{1-Social-demographic questionnaire \\ characteristics}

Socidemographic characteristics questionnaire consisted of seven items questioning the age, gender, maternal and paternal education level of the students, the type of high school they graduated from, the order of preference for medical school, and the economic status of their families.

\section{2- Factors affecting the choice of profession}

The second form in our study consisted of 11 items including some expressions that were thought to be effective in choosing a medical school.

The study data were analyzed with the SPSS version 17.0 software [16]. For the descriptive statistics, non-numerical data were expressed in number and percentage, and numerical data were expressed in mean and standard deviation. We evaluated 11 factors, which we thought to be effective in the choice of medical faculty, with 
a 5-point Likert type scale ranging from one (1) to five (5) according to their importance level (1=most important, 2=important, 3=uncertain, 4=not important, 5=least). The Mann-Whitney $U$ test was used to compare the factors that would affect them. Statistical significance level considered as $p<0.05$.

\section{Results}

Of the students participating in the study, $58.1 \%(n=97)$ were female, $41.9 \%(n=70)$ were male, and the mean age was $18.92 \pm 0.97$ years. A total of $45.5 \%$ of the students graduated from Science High School, 40.1\% from Anatolian High School, and $14.3 \%$ from other types of high school. The mothers of the students were mostly university graduates with a rate of $37.7 \%$ $(n=63)$ and high school graduates with a rate of $23.4 \%(n=39)$, and the fathers were university graduates with a rate of $49.7 \%(n=87)$ and high school graduates with a rate of $23.4 \%(n=39)$. It was determined that a total of $38.3 \%(n=64)$ of the students perceived their financial situation as good, $58.1 \%(n=97)$ as average, and $1.2 \%$ $(n=2)$ as bad. A total of $94.0 \%(n=157)$ of the students preferred medical faculty in the 1st and 2 nd place in the university preference form (Table 1).

The factor that the participants found "the most important" factor in their choice of profession with a rate of $36.5 \%(n=61)$ was that physicians have professional guarantee. The "important" factors in choosing the Faculty of Medicine were willingness to help people with a rate of $53.9 \%(n=90)$, respectability of medicine with a rate of $53.3 \% \quad(n=89)$, employment guarantee with a rate of $51.5 \% \quad(n=86)$, and the opportunity to work independently with a rate of $35.3 \% \quad(n=59)$. In addition, a total of $33.5 \%(n=56)$ of the participants stated that they chose medical school for their desire to earn a lot of money. The factors that the students considered insignificant in their choice of profession were having a health problem in their family or in themselves with a rate of $37.7 \%(n=63)$, guidance of teacher with a rate of $29.9 \%$ ( $n=50)$, and being impressed by their physician acquaintances with a rate of $30.5 \%$ $(n=51)$ (Table 2). When the demographic data of the students were compared with the factors

Table 1. Demographic data of first year medical faculty students

\begin{tabular}{ll}
\hline Age & (AM $\mathbf{n}$ (\%): 18.92 \pm 0.97 \\
\hline Gender & $97(58.1)$ \\
Female & $70(41.9)$ \\
Male & \\
Type of high school graduated & $67(40.1)$ \\
Anatolian High School & $76(45.5)$ \\
Science High School & $24(14.3)$ \\
Other types of high school & \\
Educational status of mother & $50(29.9)$ \\
Middle School and below & $117(70.0)$ \\
High School and above & \\
Educational status of father & $28(16.7)$ \\
Middle School and below & $139(83.2)$ \\
High School and above & \\
Economic status of family & $68(40.7)$ \\
Well & $97(58.0)$ \\
Moderate & $2(1.1)$ \\
Bad & $157(94.0)$ \\
Medical school preference order & \\
1-2 & \\
3-5 & \\
\hline AM SD: Arithmetic Mean \pm Standard Deviation & \\
\hline
\end{tabular}


affecting the choice of medical school, male students found "being a physician to earn a lot of money" more important than female students $(p<0.05)$. There were statistically significant differences between the types of high schools that the students graduated from and the factors affecting the choice of faculty of medicine $(p<0.05)$. Anatolian high school graduates found the factors of the aspiration of family, the guidance of their teachers, and being influenced by doctors on television and films less important than those who graduated from other types of high school $(p<0.05)$. The students with a good and very good level of family income suggested that they preferred medicine because it was a respected profession in the society and they considered it as a more important factor than those whose family income level was bad and very poor $(p<0.05)$. Those whose fathers were with a low level of educational background considered being a physician as a more important factor due to "having health problems in their family or in themselves" compared to those whose father were with higher level of education $(p<0.05)$ (Table 3$)$.

\section{Discussion}

The results of the study showed that it was considered a "very important" factor with a rate of 36.55 and an "important" factor with a rate of $51.5 \%$ in the career choice of medical school students that physicians have the professional guarantee (Table 2). It is necessary to take other exams after other occupational training to work in state institutions in Turkey, graduates of medical school can find jobs in state institutions just after the graduation from university. In the study by Amin et al. [17], it was suggested that the most important motivation in the choice of profession of medical students was professional guarantee. The perception that medicine is one of the most qualified area of professions that successful young people can do in countries where unemployment is common is also valid for our country.

One of the factors that the students found important with a rate of $53.9 \%$ in choosing the profession of medicine was loving people and willing to help people (Table 2). There were similar results in the literature [4, 12, 18, 19]. The choice of medical school of students to love and help people is a motivation aligned with the profession that should be appreciated [20]. We may suggest that the emphasis placed on the moral side of the professions chosen by the students who choose the profession of medicine which requires a long and compelling education will positively contribute to the success and

Table 2. Distribution of answers to the effective factors in the Faculty of Medicine of the students prefer

\begin{tabular}{|c|c|c|c|c|c|}
\hline $\begin{array}{l}\text { Factors affecting the choice of Faculty } \\
\text { of Medicine }\end{array}$ & $\begin{array}{l}\text { Most } \\
\text { important } \\
\mathrm{n}(\%)\end{array}$ & $\begin{array}{l}\text { Important } \\
\mathrm{n}(\%)\end{array}$ & $\begin{array}{l}\text { Uncertain- } \\
\text { n (\%) }\end{array}$ & $\begin{array}{l}\text { Not } \\
\text { important } \\
\mathrm{n}(\%)\end{array}$ & $\begin{array}{l}\text { Least } \\
\text { important } \\
\mathbf{n}(\%)\end{array}$ \\
\hline 1. Willingness to help people & $39(23.4)$ & $90(53.9)$ & $20(12)$ & $12(7.2)$ & $6(3.6)$ \\
\hline 2. Having job guarantee & $61(36.5)$ & $86(51.5)$ & $13(7.8)$ & $5(3)$ & $2(1.2)$ \\
\hline 3. Being respected in the society & $43(25.7)$ & $89(53.3)$ & $21(12.6)$ & $9(5.4)$ & $5(3)$ \\
\hline $\begin{array}{l}\text { 4. Having health problems in my family or } \\
\text { in me }\end{array}$ & $9(5.4)$ & $25(15)$ & $40(24)$ & $30(18)$ & $63(37.7)$ \\
\hline 5. My family's request & $21(12.6)$ & $42(25.1)$ & $37(22.2)$ & $29(17.4)$ & $38(22.8)$ \\
\hline $\begin{array}{l}\text { 6. Being affected by my doctor } \\
\text { acquaintances }\end{array}$ & $11(6.6)$ & $37(22.2)$ & $33(19.8)$ & $35(21)$ & $51(30.5)$ \\
\hline 7. Want to make a lot of money & $22(13.2)$ & $56(33.5)$ & $39(23.4)$ & $27(16.2)$ & $23(13.8)$ \\
\hline $\begin{array}{l}\text { 8. Being influenced by doctors on TV and } \\
\text { movies }\end{array}$ & $8(4.8)$ & $38(22.8)$ & $43(25.7)$ & $37(22.2)$ & $41(24.6)$ \\
\hline $\begin{array}{l}\text { 9. Having the opportunity to work } \\
\text { independently }\end{array}$ & $26(15.6)$ & $59(35.3)$ & $41(24.6)$ & $20(12)$ & $21(12.6)$ \\
\hline 10. Teacher guidance & $9(5.4)$ & $37(22.2)$ & $40(24)$ & $31(18.6)$ & $50(29.9)$ \\
\hline 11. Other factors & $19(11.4)$ & $17(10.2)$ & $59(35.3)$ & $10(6)$ & $62(37.1)$ \\
\hline
\end{tabular}




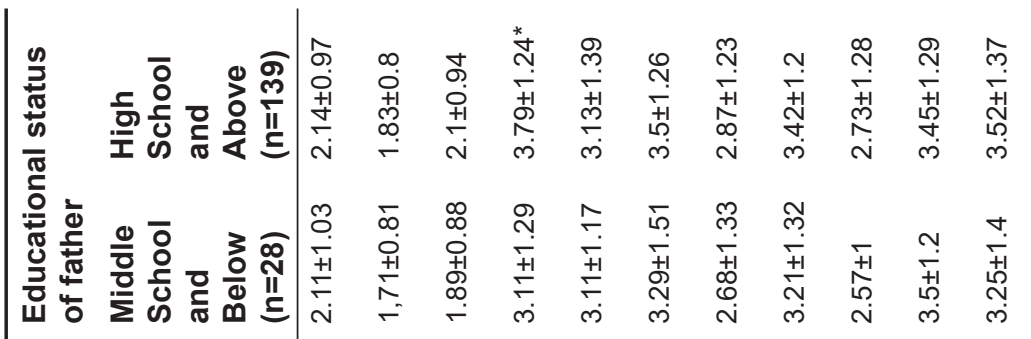

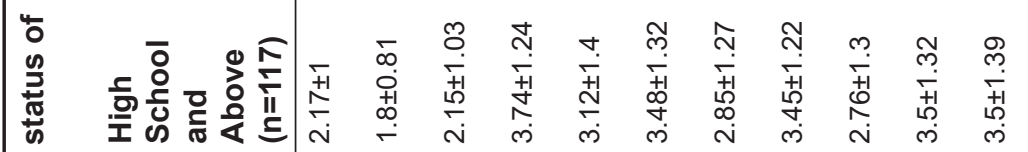

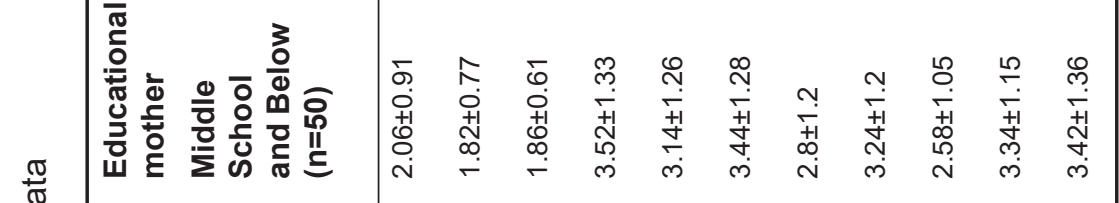
$\frac{0}{\frac{1}{2}}$

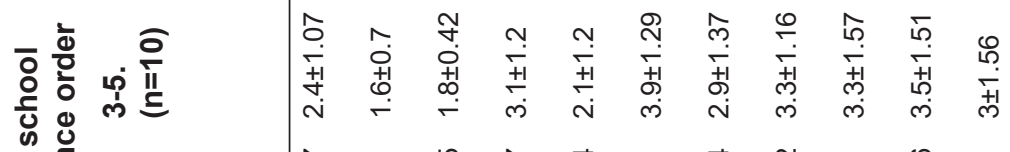

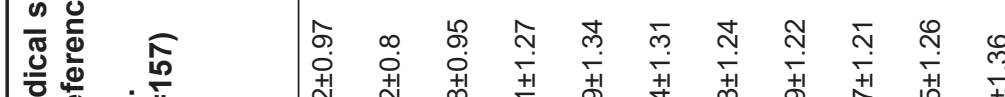

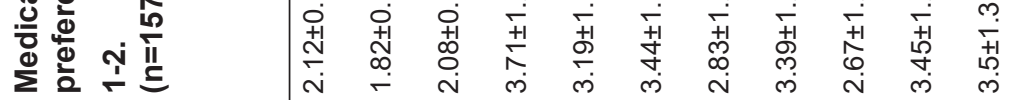

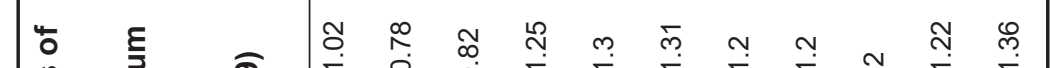

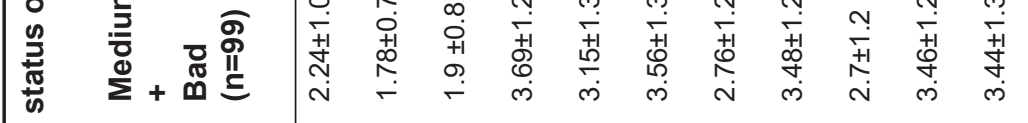

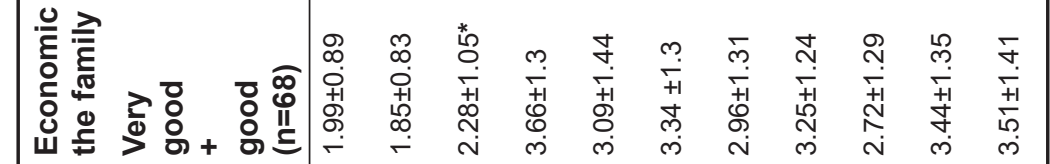

ก

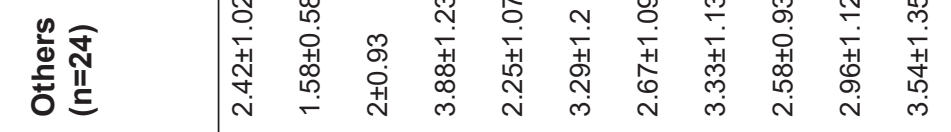

\& $\overline{0}$ व

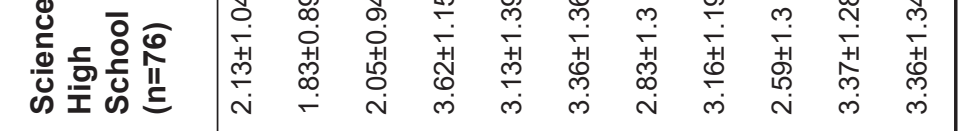

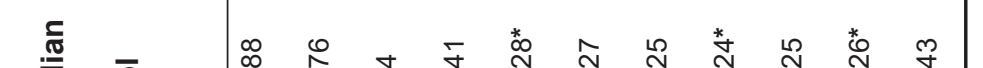

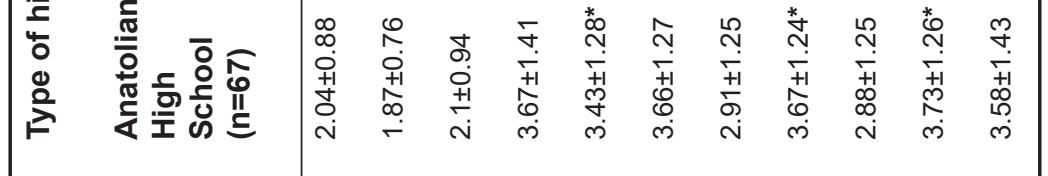

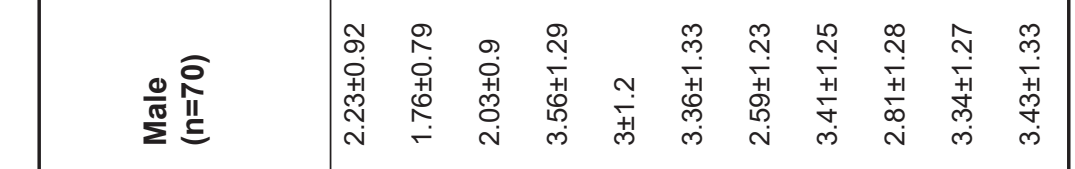

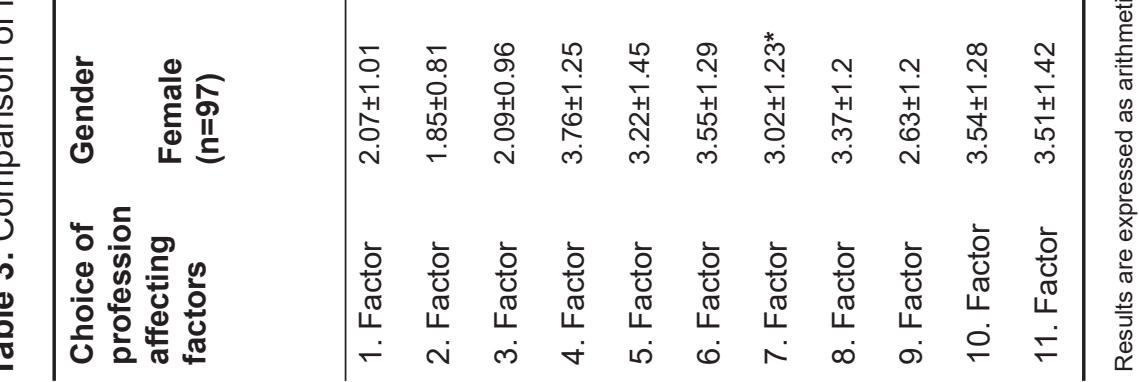


being happy in both education life and work life.

The respectability of medicine has been an important factor with a rate of $53.3 \%$ in career choice. The first values that come to mind as a socially attributed medical profession are usually that it is a respectable profession, as well as being economically satisfactory $[11,12$, $21,22]$. In the study conducted by Draper and Louw on medical students, it was suggested that the society's description of medicine as a very noble and respected profession was effective in students' career choice [8]. In our country, the first answer to the question of "what do you want to be when you grow up?" is usually "I want to be a doctor". Therefore, students entering faculty of medicine consider themselves individually successful as a result of exams, as well as stepping into a satisfactory profession in many ways according to the perspective of the society.

The factors that students consider to be the most insignificant in choosing medical school were "having a health problem in the family or in themselves", "guidance by teachers" and "being impressed by their doctor acquaintances" (Table 2). In Tiwari's study, it was observed that some students were impressed by their relatives who were physicians [12]. In the present study, it was not questioned whether the students had a physician relative or not, but it was understood that they chose medicine by their own will rather than guidance of teacher or other external factors (Table 2). Most of the participating students $(n=143)$ were graduates of Science and Anatolian High Schools entered by an exam. The students who also scored better than other students in the university entrance exam may have been more free to make their own decisions about choosing a profession. The fact that a total of $94.0 \%$ of the students chose medical faculty in their $1 \mathrm{st}$ and 2 nd place in the university preference form shows that they were determined to become a physician. However, families played an important role with a rate of $25.1 \%$ in the choice of medical school. In the literature, there are studies with results that family influence was higher. For example, families were effective in their children's choice of medical faculty with a rate of $38.2 \%$ in the study by Al Hemiary et al. [23] and with a rate of $87 \%$ in the study by Saad et al. [24]. In countries where traditional values are effective, families can be more effective in career choice of their children. The reason behind this attitude is that families direct their successful children to the medical school against the danger of unemployment; therefore, they want to ensure dignity and to economically guarantee them.

A total of $58.1 \%$ of the students participating in the study were female and $41.9 \%$ were male. More male students than female students stated that they chose medicine because they wanted to earn more money; the girls found this factor less important compared to the boys. In the literature, there are studies showing that men care more about prestige, social status and economic reasons compared to women when choosing medical school [4, 25-28]. In the study by Neittaanmäki et al. [29], more female physicians than male physicians stated that they chose the profession to help people, and it was found that men were more interested in the prestige and the economic aspects of the profession. In the study by Hyppölä et al. [21], men similarly stated that they chose to become physicians because it was a highly-paid and high-status profession. This may be due to the gender role put on men in making money. Most of the students $(58.0 \%)$ participating in the present study were children of middle-income families. The students with a good and very good level of family income suggested that they preferred medicine because it was a respected profession in the society and they considered it as a more important factor than those whose family income level was bad and very poor $(p<0.05)$. According to the students, "being a doctor" may be considered and preferred as a profession that ensures the continuity of prestige and economic conditions in the society.

The results of the study suggest that the most important factor for first-year students in the faculty of medicine at a state university in Turkey while choosing medical profession is the guarantee of employment. In addition, loving people and the fact that medicine is a respected profession were also effective in choosing a medical school. Male students were found to be more interested in the economic aspects of medicine than female students. We hope our findings provide useful information for students, academicians and policy makers who want to become physicians.

\section{Limitations}

This study was conducted in a single faculty and in a single classroom with a small sample 
size. Further studies should be done on larger populations in other medical faculties, and other motivations and reasons of young people who want to become physicians should be identified.

Conflict of interest: No conflict of interest was declared by the authors.

\section{References}

1. Brown D. The role of work and cultural values in occupational choice, satisfaction, and success: A theoretical statement. J Counsel \& Dev 2002;80:48-56. https://doi.org/10.1002/j.1556-6678.2002.tb00165.x

2. Yang E, Wong SC, Hwang M, Hwang M, Heppner MJ. Widening our global view: The development of career counseling services for international students. J Career Dev 2002;28:203-213. https://doi. org/10.1177/089484530202800305

3. Razon N. Meslek seçimi ve mesleğe yöneltme. Eğitim ve Bilim 1983;8:23-31.

4. McManus IC, Livingston G, Katona C. The attractions of medicine: the generic motivations of medical school applicants in relation to demography, personality and achievement. BMC Med Educ 2006;6:1-15. https://doi. org/10.1186/1472-6920-6-11

5. Cansever Z, Avşar ÜZ, Acemoğlu H, Çayır Y, Avşar Ü. Atatürk Üniversitesi Tıp Fakültesi birinci sınıf öğrencilerinin tıp fakültesini tercih nedenleri ve tıp eğitiminden beklentileri. Konuralp Tıp Dergisi 2014;6:17-21. https://doi.org/10.18521/ktd.40135

6. Alper Z, Özdemir H. Uludağ Üniversitesi Tıp Fakültesini tercih eden öğrencilerin kimi sosyo-demografik özellikleri ve mesleğe bakış açıları. Uludağ Üniversitesi Tıp Fakültesi Dergisi 2004;30:93-96.

7. Tımbıl S, Özan S, Velipaşaoğlu S, Gürsel Y, Taşkıran C, Musal B. Tıp eğitimine yeni başlayan öğrencilere yönelik durum değerlendirme çalısması: iki yıla ait verilerin karşılastırması. Tıp Eğitimi Dünyası 2007;26:111.

8. Draper C, Louw G. What is medicine and what is a doctor? Medical students' perceptions and expectations of their academic and professional career. Med Teach 2007;29:100-107. https://doi. org/10.1080/01421590701481359

9. Shahab $F$, Hussain $H$, Inayat $A$, Shabab A. Attitudes of medical students towards their career- perspective from Khyber-Pukhtunkhwa. J Pak Med Assoc 2013;63:1017-1020.

10. Bozgeyikli H, Derin S, Toprak E. Üniversite öğrencilerinin mesleki değer algıları. Uluslararası Güncel Eğitim Araştırmaları Dergisi 2016;2:139-156.

11. Girasek E, Molnár R, Eke E, Szocska M. The medical career choice motivations -results from a Hungarian study. Central European J Med 2011;6:502-509. https:// doi.org/10.2478/s11536-011-0034-0
12. Tiwari R, Jain V, Arya R, Dwivedi S, Shrivastava D, Tiwari S. A study to assess the perceptions of first year medical students for choosing medical school as a career. Int J Res Med Sci 2016;4:2649-2655. https:// doi.org/10.18203/2320-6012.ijrms20161926

13. Ceylan E, Cinser BB, Soytürk $S$, Şengün $T$, Erbay $H$. Bir tıp fakültesi öğrencilerinin meslek tercihinde etkili olan faktörler. J Med Educ Inform 2017;3:02-12.

14. Yükseköğretim Bilgi Yönetim Sistemi. Erişim adresi: https://istatistik.yok.gov.tr/. Erişim tarihi 05 Temmuz 2020

15. Yükseköğretim Kurulu. Erişim adresi: https://www.yok. gov.tr/. Erişim tarihi 08 Temmuz 2020

16. IBM Corp. Released 2017. IBM SPSS Statistics for Windows, Version 25.0. Armonk, NY: IBM Corp.

17. Amin Z, Tani M, Eng KH, Samarasekara DD, Huak CY. Motivation, study habits, and expectations of medical students in Singapore. Med Teach 2009;31:560-569. https://doi.org/10.3109/01421590903193554

18. Sulong S, McGrath D, Finucane P, Horgan M, O'Flynn $\mathrm{S}$, O'Tuathaigh $\mathrm{C}$. Studying medicine-a cross-sectional questionnaire-based analysis of the motivational factors which influence graduate and undergraduate entrants in Ireland. JRSM Open 2014;5:1-8. https://doi. org/10.1177/2042533313510157

19. Gąsiorowski J, Rudowicz E, Safranow K. Motivation towards medical career choice and future career plans of Polish medical students. Adv Health Sci Educ Theory Pract 2015;20:709-725. https://doi.org/10.1007/ s10459-014-9560-2

20. Kusurkar R. Motivation in medical students: a $\mathrm{PhD}$ thesis report. Perspect Med Educ 2012;1:155-157. https://doi.org/10.1007/s40037-012-0016-1

21. Hyppölä H, Kumpusalo E, Neittaanmäki L, et al. Becoming a doctor--was it the wrong career choice? Soc Sci Med 1998;47:1383-1387. https://doi. org/10.1016/S0277-9536(98)00208-1

22. Goel S, Angeli F, Dhirar N, Singla N, Ruwaard D. What motivates medical students to select medical studies: a systematic literature review. BMC Med Educ 2018;18:110. https://doi.org/10.1186/s12909-018-1123-4

23. Al Hemiary N, Al Nuaimi AS, Al Saffar H, Randall I. Why people apply to medical school in Iraq? J Med Educ Curric Dev 2017;4:1-5. https://doi. org/10.1177/2382120517726997

24. Saad SMA, Fatima SM, Faruqi AA. Students' views regarding selecting medicine as a profession. J Pak Med Assoc 2011;61:832-836.

25. Wierenga AR, Branday JM, Simeon DT, Pottinger A, Brathwaite B. Motivation for and concerns about entering a medical programme. West Indian Med J 2003;52:304-310. 
26. Millan LR, Azevedo RS, Rossi E, De Marco OLN, Millan MPB, de Arruda PCV. What is behind a student's choice for becoming a doctor?. Clinics (Sao Paulo) 2005;60:143-150. https://doi.org/10.1590/S180759322005000200011

27. Özan S, Karademir S, Velipaşaoğlu S, Gürsel Y, Taşkıran C, Musal B. Dokuz Eylül Üniversitesi Tıp Fakültesi'nde tıp eğitimine yeni başlayan öğrencilere yönelik durum değerlendirme çalışması. Tıp Egitimi Dünyası 2006;23:12-18.

28. De Conick M, Bergeron P, Bourbonnais R. Woman physicians in Quebeck. Social. Soc Sci Med 1997;44:1825-1832. https://doi.org/10.1016/S02779536(96)00292-4

29. Neittaanmäki L, Luhtala R, Virjo I, et al. More women enter medicine: young doctors' family origin and career choice. Med Educ 1993;27:440-445. https://doi.org/ 10.1111/j.1365-2923.1993.tb00298.x

Acknowledgments: The authors are grateful to the students who participated in the study.

Ethics committee approval: The study approval was obtained from the NonInterventional Ethics Committee of the Facult of Medicine, Pamukkale University (date: 01.12.2020 and number: 2020/07).

\section{Author contribution}

S.Ö.Y. constructed the main idea and hypothesis of the study. S.Ö.Y., K.F.T., O.Y., M.C.K. and M.B. developed the theory and organized the material method section. N.A.Ç. and $\mathrm{H}$.Ş. analyzed the data in the results section. The discussion section of the article was written by S.Ö.Y., K.F.T., O.Y., M.C.K., M.B. and S.Ö.Y. reviewed, made the necessary corrections, and approved. Also, all authors discussed the whole study and approved its final version. 